\title{
Frequency of the CCR5-delta 32 chemokine receptor gene mutation in the Lebanese population
}

\author{
W. Karam, ${ }^{1}$ R. Jurjus, ${ }^{2}$ N. Khoury, ${ }^{3}$ H. Khansa, ${ }^{3}$ C. Assad, ${ }^{4}$ P. Zalloua ${ }^{5}$ and A. Jurjus ${ }^{2}$
}

SUMMARY A direct correlation between HIV infection and mutation in the chemokine receptor (CCR5) gene has been established. However, such correlation has never been investigated in Lebanon. We report the frequency of the CCR5-delta 32 mutation in a random sample of 209 healthy, $\mathrm{HIV}-1$ seronegative Lebanese aged 19-68. Overall, 4.8\% were heterozygous for the mutation. Homozygosity was absent from our sample. The frequency for the CCR5-delta 32 allele was $2.5 \%$. Distribution of the mutation was unaffected by sex, age, religion or educational level. The frequency in the Lebanese population is consistent with that in the origin of the mutation in northern Europe. This could be attributed to a gene flow into the Middle East from northern Europe.

\section{Introduction}

According to a World Health Organization report, 42 million people were living with HIV/AIDS worldwide in 2002; 92\% were adults, $46 \%$ women, and $8 \%$ children under the age of 15 . This resulted in 3.1 million deaths in 2002. In North Africa and the Middle East alone, 550000 people are currently living with HIV/AIDS [1]. In Lebanon, the cumulative number of reported HIV/AIDS cases reached 987 by the end of 2002, while the estimated number could be as much as 3000 [2].

It has been established that infection by HIV-1 is influenced by a mutation in the chemokine receptor $(C C R 5)$ gene $[3,4]$. The product of the CCR5 gene encodes a
CC-type seven-transmembrane G-proteincoupled chemokine receptor that binds RANTES, MIP-1alpha and MIP-1beta, and has been shown to mediate entry of Mtropic HIV-1 strains into target cells [5-7]. CCR5 also serves as an entry co-receptor for primary human immunodeficiency virus strains that infect monocytes and macrophages [7-9]. The CCR5 gene is located on chromosome 3p21.3. Individuals resistant to repeated exposure to the virus have been shown to be homozygous for a $32 \mathrm{bp}$ deletion in the CCR5 gene [5,6]. Heterozygosity for the mutation is associated with a slower progression to AIDS following HIV1 infection with a typical delay of $2-4$ years $[4,6,10]$. The $32 \mathrm{bp}$ deletion in the gene causes a frame shift at amino acid 185 ,

${ }^{1}$ Faculty of Public Health, Balamand University, Beirut, Lebanon.

${ }^{2}$ Faculty of Medicine, American University of Beirut, Beirut, Lebanon.

${ }^{3}$ Faculty of Public Health, Lebanese University, Beirut, Lebanon.

${ }^{4}$ Division of Medical Sciences and Public Health, Lebanese Council for Scientific Research, Beirut,

Lebanon.

${ }^{5}$ Chronic Care Centre, Hazmieh, Lebanon.

Received: 14/05/03; accepted: 14/09/03

البحلة الصحية لشرق المتو سط، منظمة الصحة العالمية، البحلد العاشر، العلدان ع-ه، ع • • 
which results in a stop codon and premature truncation within the third extracellular domain. Analysis of the infectability of cells of 3 different genotypes by Liu et al. demonstrated that HIV-1 replicated in wild-type homozygous cells but failed to replicate in homozygous delta-32 cells, whereas replication of the virus in cells heterozygous for the mutation proceeded at an intermediate rate [5].

In this study we report the frequency of the CCR5-delta 32 mutation in the Lebanese population.

\section{Methods}

The participants were selected from Lebanese adults attending the blood bank of a major teaching hospital in Beirut, Lebanon over a 6-month period between July and December 2001. Sample size was 220. Participants were healthy, HIV-1 seronegative, of both sexes, and ages ranged from 19 to 68 years. Palestinian, Syrian, and Armenian donors were not included in the study. None of the blood samples collected tested positive for HIV. In addition, the donated blood was further screened for antibody titres and potential pathogens before being considered suitable for donation. Every third qualified donor was included in the study; people who donated blood at night or on Sundays, however, were excluded. The donors were not inconvenienced in any way. An anonymous questionnaire was completed for each participant. The questionnaire included questions relating to marital status, number of sex partners, practice of safe sex, drug use, history of blood or blood products transfusion, and whether the participant had previously been tested for HIV. Institutional ethical clearance and informed consent of the blood donors were obtained. We followed the Helsinki Declaration (1964, amended in 1975 and 1983) of the World Medical Association.

About $2 \mathrm{~mL}$ of donated peripheral venous blood was collected from each participant. The GFX genomic blood DNA purification kit (Amersham Pharmacia Biotech Europe GmbH, Freiburg, Germany) was used to extract genomic DNA from white blood cells following the lysis of red blood cells. DNA was eluted in $100 \mu \mathrm{L}$ molecular biology grade water and stored at $-20{ }^{\circ} \mathrm{C}$. DNA concentrations were determined spectrophotometrically.

Polymerase chain reaction was performed following the methods of Martinson et al. [11]. Briefly, $100 \mathrm{ng}$ of genomic DNA was denatured at $94{ }^{\circ} \mathrm{C}$ for 10 minutes, following which it was subjected to 30 cycles of denaturation, annealing and extension. The last cycle was followed by an incubation at $72{ }^{\circ} \mathrm{C}$ for 10 minutes. The reaction mixture of $50 \mu \mathrm{L}$ contained, $50 \mathrm{mmol} \mathrm{KCl,} 10 \mathrm{mmol}$ Tris-HCl, $\mathrm{pH}$ 8.3, $800 \mu \mathrm{mol} \mathrm{dNTPs,} 100 \mu \mathrm{g} / \mathrm{mL}$ gelatin, 10 pmoles of each of the CCR5-specific forward and reverse primers, and 1.5 units of Taq polymerase enzyme (GibcoBRL Life Technologies GmbH, Karlsruhe, Germany). Electrophoresis was performed in Tris-Borate EDTA running buffer and polymerase chain reaction products were detected in $2 \%$ agarose containing $1 \mu \mathrm{g} / \mathrm{mL}$ ethidium bromide, and visualized by transillumination with ultraviolet light [11].

Cross contamination was avoided by using pipette-tips fitted with aerosol barrier filters, and frequent decontamination of work surfaces with short ultra-violet light irradiation and diluted bleach. Carry-over contamination was prevented by physically separating the extraction, amplification and detection areas.

Both deleted and normal PCR products were extracted from agarose gels using the PCR product clean-up kit from (Roche

بلملة الصحية لشرق المتو سط، منظمة الصحة العالمية، المحلد العاشر، العددان ع-0، ع • • 
Molecular Biochemicals GmbH, Mannheim, Germany) and dideoxytermination cycle sequencing (Applied Biosystems, Foster City, California,) of normal and deleted polymerase chain reaction products was performed to confirm the identities of amplicons and to determine the exact nature and location of the deletion along the CCR5 gene.

Eleven samples did not yield amplifiable DNA, consequently, the effective number of donors included in the study was 209.

Statistical analysis was performed and individual parameters were tested for significance by analysis of variance.

\section{Results}

Overall, $4.8 \%$ of the people we studied were heterozygous for the mutation; homozygosity was not found. The frequency for the CCR5-delta 32 allele was $2.5 \%$. Distribution of the mutation was unaffected by sex $(P=0.21)$, age $(P=0.41)$, or education level $(P=0.62)$, and was similar among the religious groups that we examined $(P=0.43)$ (Table 1$)$. The sequencing of the polymerase chain reaction products purified from agarose gels confirmed their identity with that of the CCR5 gene (GenBank X91492). Also, the nature and location of the deletion identified by sequencing of the deleted polymerase chain reaction products were identical to that reported by Liu et al. [5].

\section{Discussion}

A north to south gradient in the delta 32 allele frequency has been reported across Europe, with the highest allele frequencies in the Finnish and other populations living around the Baltic Sea (10\%-20\% heterozygous; $1 \%$ homozygous), and the lowest in

\begin{tabular}{|c|c|c|c|}
\hline Variable & $\begin{array}{c}\text { No. with } \\
\text { CCR5/CCR5 }\end{array}$ & $\begin{array}{c}\text { No. with } \\
\text { CCR5/CCR5- } \\
\text { delta } 32\end{array}$ & $\begin{array}{c}P \text { - } \\
\text { value }^{a}\end{array}$ \\
\hline Total & 199 (95.2\%) & $10(4.8 \%)$ & \\
\hline \multicolumn{4}{|l|}{ Sex } \\
\hline$M$ & 112 & 6 & 0.21 \\
\hline $\mathrm{F}$ & 87 & 4 & \\
\hline \multicolumn{4}{|l|}{ Age (years) } \\
\hline Range & $19-68$ & $20-60$ & 0.41 \\
\hline$\leq 40$ & 125 & 5 & \\
\hline$>40$ & 32 & 3 & \\
\hline Unknown & 42 & 2 & \\
\hline \multicolumn{4}{|l|}{ Ethnicity } \\
\hline Christian & 119 & 8 & 0.43 \\
\hline Muslim & 40 & 2 & \\
\hline Unknown & 40 & 0 & \\
\hline \multicolumn{4}{|l|}{ Education } \\
\hline University & 84 & 5 & 0.62 \\
\hline High school & 63 & 3 & \\
\hline Technical & 31 & 2 & \\
\hline Other & 21 & 0 & \\
\hline
\end{tabular}

${ }^{a} A / l \mathrm{P}$-values were $>0.05$, indicating no significant effect of age, sex, education or ethinicity in this case on the mutation frequency.

Sardinia and Greece, where the frequency drops to almost zero [11-13]. The mutation is also seen at very low frequencies in populations from Saudi Arabia, Syrian Arab Republic, Islamic Republic of Iran, Tunisia, Morocco, Cyprus (Greek), India, Pakistan and Asia. It is virtually absent in native populations from sub-Saharan Africa and Oceania [11-15]. Based on the demographic distribution, it is believed that the mutation arose in northern Europe in response to selective pressures such an infection epidemic. Our results are consistent with reports in the medical literature: we detected the mutated allele in our study population at

لبحلة الصحية لشرق المثتوسط، منظمة الصحة العلمية، البحلد العاشر، العدذان ع-0، ع • • 
a frequency of $2.5 \%$, which is close to what is being reported in the Syrian Arab Republic (1.4\%), Islamic Republic of Iran (2.4\%), Tunisia (1\%), Morocco (1.5\%) and Cyprus (2.8\%) [15].

The frequency in the Lebanese population is consistent with the location of the origin of the mutation in northern Europe. This could be attributed to a gene flow into the Middle East from northern Europe. In addition, frequencies of the deletion gradually decrease as the distance from Europe becomes greater and it is virtually absent in Asia, the Far East, Oceania and South Africa. We therefore propose that, in addition to the gradient seen in Europe, a gradient outside Europe also exists for the mutation across the Middle East region and into Asia, the Far East and Oceania and across Europe into Africa. This is in accord with a single point of origin for the mutation located in northern Europe, where the highest frequencies for the deletion have been reported.

\section{Acknowledgement}

The authors would like to acknowledge the support of the Lebanese Scientific Research Council for funding the study.

\section{References}

1. AIDS epidemic update. Geneva, World Health Organization, 2002.

2. National AIDS program annual report 2002. Beirut, Lebanon, Ministry of Public Health, 2002.

3. Huang $\mathrm{Y}$ et al. The role of a mutant CCR5 allele in HIV-1 transmission and disease progression. Nature medicine, 1996, 2(11):1240-3.

4. Fowke KR et al. Resistance to HIV-1 infection among persistently seronegative prostitutes in Nairobi, Kenya. Lancet, 1996, 348(9038):1347-51.

5. Liu R et al. Homozygous defect in HIV-1 coreceptor accounts for resistance of some multiply-exposed individuals to HIV-1 infection. Cell, 1996, 86(3):36777.

6. Dean M et al. Genetic restriction of HIV-1 infection and progression to AIDS by a deletion allele of the CKR5 structural gene. Hemophilia growth and development study, Multicenter AIDS cohort study, Multicenter hemophilia cohort study, San Francisco City cohort, ALIVE study. Science, 1996, 274(5290): 1856-62.
7. Dragic T et al. HIV-1 entry into CD4+ cells is mediated by the chemokine receptor CC-CKR-5. Nature, 1996, 381(6584): 667-73.

8. Alkhatib G et al. CC CKR5: a RANTES, MIP-1alpha, MIP-1beta receptor as a fusion cofactor for macrophage-tropic HIV1. Science, 1996, 272(5270):1955-8.

9. Zhao SF et al. Chemokine receptors and the molecular basis for human immunodeficiency virus type 1 entry into peripheral hematopoietic stem cells and their progeny. Journal of infectious diseases, 1998, 178(6):1623-34.

10. Michael NL et al. The role of viral phenotype and CCR-5 gene defects in HIV-1 transmission and disease progression. Nature medicine, 1997, 3(3):338-40.

11. Martinson JJ et al. Global distribution of the CCR5 gene 32-basepair deletion. Nature genetics, 1997, 16(1):100-3.

12. Libert $\mathrm{F}$ et al. The deltaccr5 mutation conferring protection against HIV-1 in Caucasian populations has a single and recent origin in Northeastern Europe. Human molecular genetics, 1998, 7(3): 399-406.

بلملة الصحية لشرة المتو سط، منظمة الصحة العالمية، البحلد العاشر، العادان ع-0، ع • • 
13. Magierowska $M$ et al. Distribution of the CCR5 gene 32 base pair deletion and SDF1-3' A variant in healthy individuals from different populations. Immunogenetics, 1998, 48(6):417-9.

14. Szalai $C$ et al. High frequency of the CCR5 deletion allele in Gypsies living in Hungary. Immunology letters, 1998, 63(1):57-8.
15. Lu Y et al. Genotype and allele frequency of a 32-base pair deletion mutation in the CCR5 gene in various ethnic groups: absence of mutation among Asians and Pacific Islanders. International journal of infectious diseases, 1999, 3(4):186-91.

\section{Genetics in developing countries}

Low- to middle-income countries vary in their capacities in medical genetics. Some may not have the resources to set up appropriate genetic services. Others provide genetic services but need assistance to improve equity of access to these services. The World Health Organization is supporting country capacity building by constructing educational modules and pilot studies to develop national community genetics, including the ethical, legal and societal implications (ELSI).

Source: WHO Fact sheet: genetics and health Available at: http://www.who.int/genomics/en/E_hgn__final.pdf

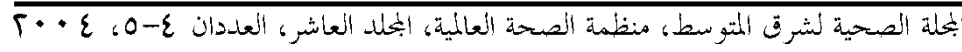

